\title{
A Brief Analysis of the Sad Ending in the Innocent
}

\author{
Wei Xie \\ Tianhe College of Guangdong Polytechnic Normal University, Guangzhou 510540, China. \\ 645321570@qq.com
}

Keywords: The Innocent; sad ending; the Cold War.

\begin{abstract}
The paper analyses The Innocent at the base of the love story to unfold the theme. The first part of the paper summarizes the paper and its context. The second part introduces Ian McEwan's writing inspiration and the social environment that the writer set in The Innocent. The third part analyses the love of Leonard and Maria and write out the sad ending of the love and the explanation of the incomplete love. The forth part stresses the causes of the sad ending. Finally, the summary of the paper and research significance were wrote out.
\end{abstract}

\section{Introduction}

Ian McEwan is one of the outstanding contemporary English writers, and his works arouse great interest in literary criticism. The Innocent set in Berlin during the Cold War, based on an actual incident which tells of the secret tunnel under the Soviet sector which the British and Americans built in 1954 to gain access to the Russians' communication system. The protagonist, Leonard Marnham was a 25-year-old, naive, unsophisticated Englishman, assigned to a British-American surveillance team in Cold War Berlin. He sets up and repairs the tape recorders used in the tunnel. He falls in love with Maria Eckdorf, a 30-year-old divorced German likewise promises to loosen the bonds of his ordinary life [1]. But the promise turns to horror in the course of one terrible evening--a night when Leonard Marnham learns just how much of his innocence he was willing to shed. Leonard and Maria tried to conceal evidence of the murder, which caused him to betray the project. Saving himself from a prison sentence, Leonard must be return back to England. A coda, set 30 years later, solves many of the remaining mysteries, and suggests the depth of innocence and false knowledge at play back in the days of high-spying [2].

The paper learns that the love of Leonard and Maria is with no result through their encounter, falling in love and the separation of them at the end, which exactly expresses the incomplete love of them. According with the analysis, the main causes of their sad ending love are their personal characters, the causes of cold war and Maria's marriage experience. The paper exposes that the effect and the hurt of the Cold War has made people and even all the society become the innocent, hoping this can afford a new view to the effects of the Cold War [3-5].

\section{Writing Inspiration and Social Environment of The Innocent}

The novel, The Innocent, was adapted by McEwan through a real story which was about the project of a joint between CIA and MI6. McEwan witnessed the sufferings and he was also one of the innocent during the Cold War period. In general, McEwan wrote this novel basing on a real story with his own experience and investigation of the Cold War.

In The Innocent, McEwan set the social environment of the story which took place at the beginning of 1950s. Since the end of the 1940s, the Cold War between the East and West has become increasingly fierce, and Berlin has become an important issue in the Cold War.

As a British, Leonard was sent to Germany to be a spy man. He worked as a post man but actually his job was to intercept the information from Soviet Union. He fell in love with a woman who was a German and whose parents were living in East Germany. Thus, their position backgrounds were quite different. It was impossible for Leonard to let Maria know his secret identity, so it's hard for them to be together forever. 


\section{Love of Leonard and Maria}

Leonard was a freshman of Berlin and had no friend there just except Bob Glass who was actually his superior. Maria worked as a typist and translator at a small British Army vehicle workshop in Spandau. There was an ex-husband called Otto who appeared unpredictably two or three times in a year to demand money and sometimes smack her head.

One day Leonard was brought to a bar by Glass as well as his friend. That time he got a note from Maria which was asked Leonard to invite her to dance. Leonard sat down and made a conversation with and knew some facts of Maria including her address. It was on the eighth or ninth day after their encounter that Glass let him rest. He wrote a letter to Maria but he could not wait for at least three days for her answer, so after a long time struggle in his mind he finally decided to send the letter by himself and pretended to come across with her. Luckily, he met Maria, and everything worked as his expectation that they fell in love.

The love of Leonard and Maria was very intense. Maria made Leonard become a man with so much passion of life and never feel tired after work because he was going to meet Maria. Leonard had never in his life felt so uncomplicatedly happy. Maria had all her orgasms because of Leonard. Once, something occurred in Leonard's mind, which was that he wanted to conquer Maria when they were making love. Thus, gradually, she did not want to be making love to him and she left him because she was attacked by him. After a long time persistency, Leonard got Maria back and finally they began again on different terms. They were going to marry, but in the night of their engagement an unwelcome visitor Otto came up. They brawled, and Otto was killed by Leonard by mistake. In order to escape from the punish of criminality, they hacked Otto's body into pieces and put them into the boxes and brought it to the tunnel where he worked adventurously, which he thought it was must safer. Unfortunately, their tunnel was exposed and the two boxes with Otto's body were found. He was innocent, that he knew, because that was self-defend. However, he was recalled back to England. With the suspicion that Maria had an affair with Glass, Leonard left Berlin and Maria could never heard from him.

\section{The Causes of the Sad Ending}

\subsection{Causes of the Personal Characters.}

As an employee of England Post Office, Leonard went to Berlin alone to be a fresh man there. He was not an outgoing people because he never went to make new friends on his own initiative, even his acquaintance with Maria was because of Maria's asking note and the push of Glass and Russell. Cowardice was also one of his personal characters. He was afraid to do something unsuccessful and hopeless. Another important character of Leonard was that he was an oversensitive guy. He could have been with Maria, because they had made a plan that Maria would go to London in a month when he was being recalled to England. However, Leonard did not trust Maria and thought that something must be taken place between Maria and Glass, which meant that she had betrayed him. Actually, the truth was that there was nothing between Maria and Glass, and at that time Glass just wanted to help him to deal with the problem. Therefore, sadness happened because of his completely unfounded suspicion.

Maria had her own judgment when she did something, and she knew what she wanted. Thus, during their early days, Maria would not come to Leonard's flat, despite his exaggerated description of its luxuries. Because she worried that if she started spending nights away the neighbors would soon be telling each other that she had found a man and a better place to live. The authorities would hear about it, and then she would be out. She always knew what was better for her, so when she learned that it was impossible or hard for her to be together with Leonard, she would took another choice. Maria was woman who was afraid of power or mighty as well. She had divorced with Otto, but he appeared unpredictably to demand money twice or three times a year, and even beat her sometimes. She had no idea of this kind of matter because it was no use to call the police who took Otto as hero and would not punish him. 


\subsection{Causes of Maria’s Marriage Experience.}

Leonard and Maria, one came from the conqueror nation of Second World War, another came from the conquered nation, which lay the embarrassment between them Maria had a fail experience of marriage. Her ex-husband Otto still came to find her to ask money or even hit her after they divorced. It was a big blow to Maria because of the misfortune marriage. For those divorced women, they are more likely to be in the shadow; and be inferiority.

Leonard even was a man with no sex experience. Although both of them ignored the secular vision and were together, Leonard would find out that Maria would question the marriage, and then have fear or other irrelevant idea in mind if they stay together longer. The imbalance in psychology made Leonard became oversensitive, which played a very important role in causing the sad ending.

Leonard took Maria's fail experience of marriage to heart. The visit by Otto in the night of their engagement let Leonard wonder whether some things was going to happen, and worried about his status. Consequently, Otto was killed by Leonard by mistake, which was the direct cause for their separation.

When Glass helping him and Maria to deal with the matter, he began to suspect that Maria and Glass have done something disloyal to him, because of Maria's marriage experience, and finally he went back to England. They had a plan that Maria should have gone to London later married with him. However, because of Leonard's distrust and Maria's arrogance their love finally ended without result. Maybe they could have a happy ending if Maria was a woman without marriage experience and just a single as Leonard, and with no harassment from her ex-husband. Maria's fail marriage experience no only brought her trouble and misfortune, but also finally made Leonard become the innocent. The Innocent, adapted by a historical event, reflects that people become victim cruelly because of the fight among great powers. Not only are Leonard and Maria the innocent, but also all the people of that time. During the Cold War, such a kind of tension situation, people suffered a lot of "harm". All of them were the innocent of this war.

\subsection{Causes of the Politics and Society.}

In the novel, America had cooperation with England to build a tunnel from West Berlin to East Berlin to eavesdrop the information from Soviet Union. Leonard was a British dispatched to there as a spy. He would not have happy ending with Maria, for their totally different political position.

The background time of The Innocent was 1950s after the end of World War II and the beginning of the Cold War; the story was taken place in Berlin, a danger place with many powers' convergence. After the Second World War, Berlin, where Leonard and Maria's encounter happened, was a scene of devastation and just like a living hell. In this extremely precarious era, however, their love was impossible to exist completely and normally. They both were the innocent of that time.

In short, it was unexpected that Leonard and Maria could not have happy ending. Because the society background at that time would not allow they to develop a love of two that one was from victorious county and the other from conquered county, and they had different position. Therefore, the sad ending of them was inevitable.

\section{Summary}

The paper explores the theme of the novel The Innocent at the base of the love story between Leonard and Maria. Since living under such kind of special background of the Cold War, they separated, though they did love each other very much, and their love died with no result. However, this just is a little part of effects and hurts for the world from the Cold War. The analysis is according to The Innocent rather than at the history part. Thus, the whole view of the cold war's bad effect cannot be shown out. The Cold War is a history staff, which must take time to work out its effect. Study harder and learn more historical documents could help.

During the Cold War, every one was long for warmth. However, in this gloomy era, the incompleteness was its real identity. Though people did not participate in Cold War they still the victims of it, most directly and innocently. Luckily, people now are free from such disaster, but they have to take hearts that be prepared for danger in times of peace, and be on the alert themselves, the 
countries and the whole society against such tragedy. According to the analysis of the paper, people can know the Cold War more prosperous, and makes people realize that such kind of political activities seem nothing to do with them, but actually very close to them. Therefore, people must be on alert all the time, otherwise the next tragedy would happen again.

\section{References}

[1]. Jie Han, Zhenli Wang. Postmodern Strategies in Ian McEwan's Major Novels. Scientific Research, 2014, p. 26-38

[2]. McEwan Ian. The Innocent. Shanghai Translation Press, 2013, p. 56-66

[3]. Abbasiyannejad Mina. A Reflection of Ian McEwan's Life in His Fiction. English Language and Literature Studies, 2012, p. 16-25

[4]. Smejkalová Šárka. Characters’s Transformations in Ian McEwan’s Works. Masaryk University, 2007, p. 30-48

[5]. Information on: www.en.wikipedia.org 